\title{
Allelopathic Effect of Meskit (Prosopis juliflora (Sw.) DC) Aqueous Extracts on Tropical Crops Tested under Laboratory Conditions
}

Getahun Asrat and Ali Seid*

Department of Biology, College of Sciences, P.O. Box 1817, Bahir Dar University, Bahir Dar, Ethiopia (*alinbiot@yahoo.com).

\begin{abstract}
Phytoinhibitory effect of Prosopis juliflora aqueous extracts on tropical crops were tested under laboratory conditions. Maize, Cotton, and forage grasses (Rodus and Panicum) were used as test plants. Litter fall and under canopy soils were tested for checking allelopathic effects under natural conditions. All the extracts showed significantly negative effects on both germination and seedling growth of test crops. The effect of leaf extract was the highest, followed by litter fall, root extracts and soils respectively. However, at low concentration litter fall and root extracts showed unbalanced root growth stimulation on Zea mays, but hampered shoot growths. Since radicle growth alone cannot increase recruitment, unbalanced growth is eventually harmful to crops. Thus, we conclude that $P$. juliflora contains water-soluble allelochemicals capable of inhibiting tropical crops and not good for agroforestry.
\end{abstract}

Keywords: Agroforestry, Crops, Cotton, Grasses, Prosopis, Phytoinhibition, Ethiopia.

\section{INTRODUCTION}

Allelopathic compounds are metabolites which released from plants and can be beneficial or detrimental to the growth of receptor plants (Chang-Hung, 1999). Allelopathy ecology in natural and agricultural ecosystems has received increasing attention because of the significant reduction of important plants growth and yield reduction of crops. It is an ecological interaction primarily based on the ability of certain plant species to produce secondary chemical compounds, that exert some sort of biological effects on other organisms, many of which are still unknown (Waller, 2003).

Ecologically, allelopathic compounds might play an important role in structuring communities. The effects of allelochemicals on germination and growth of plants may occur through interference in cell division, energy metabolism, mineral uptake, and biosynthetic processes (Pasiecznik, 1999). It would have important roles to play in determining plant diversity, dominance, succession and climax vegetation as well as usefulness in agro-ecosystems. It is also expected to be an important mechanism by which newly introduced alien plants could easily invade native plant communities (Hierro and Callaway, 2003). Thus, allelopathy could be a major factor for easy domination of invasive aliens up on introduction for agroforestry purposes. 
The reason for such invasive easy establishment in areas once full of indigenous and endemic species often attributed to various reasons such as continuing anthropogenic related disturbances, such as land conversion, grazing, and habitat fragmentation, combined with international trade and climate change, indicate that these trends are likely to continue (Zainal et al., 1988).

P. juliflora, native of America, is widely cultivated in the tropics for shade, timber, forage; and its pods can be grounded into flour and used to make flat bread. The species also reported to have medicinal uses and edible lipids can be extracted from the seeds. Few decades ago, it was deliberately introduced into Eastern Ethiopia, for agroforestry purposes. Consequently, it has naturalized, salt-tolerant, growing near waterholes and along wadis at low altitude (Hedberg and Edwards, 1989).

It is now growing luxuriantly on sandy irrigated lands and dominating other plants (Hedberg and Edwards, 1989), perhaps due to its capacity to resist drought and salt stress tolerance. In 2002, a national stakeholder's workshop, $P$. juliflora was identified as one of the top three Invasive Alian Species (IAS) of Ethiopia. However, it took only few years to become not only a number one IAS, but also a controversial resource and a serious threat to biodiversity. It has significant impacts on lowlands ecosystems services and affecting livelihood. Different studies conducted in Ethiopia reveals that $P$. juliflora invasion showed both the seriousness of IAS's potential impacts on food security and rural livelihoods, and the need for a strong invasive control policy and strategy. Some authors indicated that as it has become one of the serious topics in the country, especially in eastern regions, where the majority of rural people depend on Semi-Pastoral resources (Sen and Chawan, 1970).

The effect of $P$. juliflora on the associated flora depends significantly on the density and size of the canopy. Larger individuals and greater densities have significantly greater negative impact on the associated plants. The annuals were inhibited more than perennials. The number of annuals with significant reductions in density and/or frequency under $P$. juliflora canopies was significantly greater than the number of perennials. Thus, the density of more than $50 \%$ of the associated annuals was significantly inhibited under $P$. juliflora canopies. $P$. juliflora has little or no auto-inhibition because under field condition the density of $P$. juliflora seedlings was greater under the canopy of the same species than away from them (El-Keblawy and Al-Rawai, 2006). While, some appreciate its drought hardiness and fast growing nature, others want to use it for agroforestry. Still others claimed that it has chemicals that inhibited growth of neighboring 
plants. A study showed that the allelopathic compounds could be phenolic in nature (Hedberg and Edwards, 1989). Other researchers (Kahi, 2003; Humaid and Warrag, 1998) showed that $P$. juliflora foliage and pods contain autotoxin that can inhibit growth of other plants. However, the impact of the species on tropical food and feed crops in general and under Ethiopian condition in particular, was not studied before. Therefore, studying its allelopathic effects on major tropical food (maize), feed (Panicum and Rodus grasses) and commercial crops (cotton) intended to fill an important knowledge gap regarding $P$. juliflora impacts: evaluate its suitability for tropical agroforestry and draw useful management information.

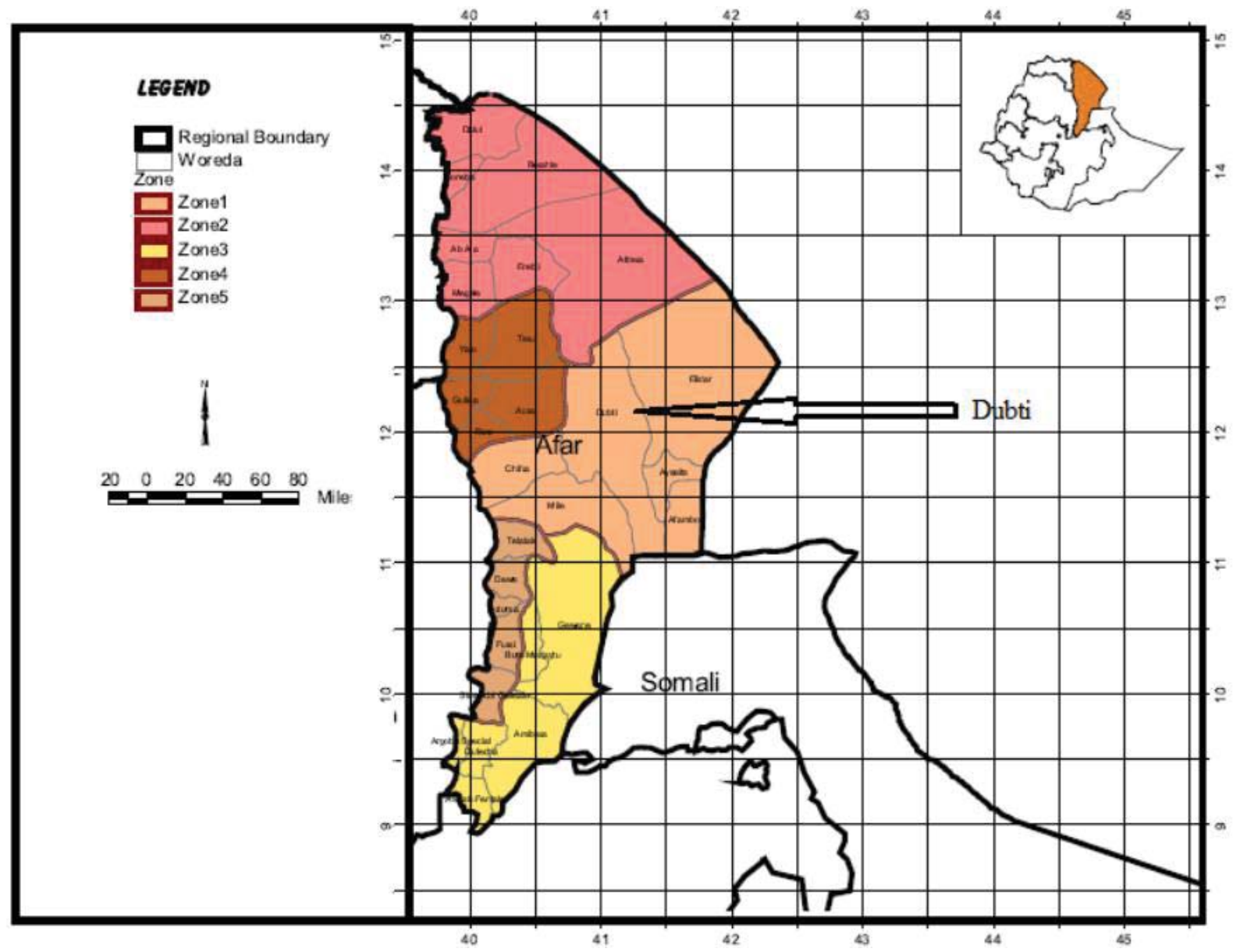

Figure 1. Location map of the study area in Afar Region, Ethiopia

\section{MATERIALS AND METHODS}

\subsection{Description of the Study Area}

The study was conducted in Dubti, East Ethiopia (Fig 1), where P. juliflora grow vigorously.

The region is part of the lower awash area with elevation of about 503 meters above sea level. 
The region has an annual mean rainfall of $564 \mathrm{~mm}$ and annual evapo-transpiration ranging between 1400 and $2200 \mathrm{~mm}$ (MOA, 2000). The region has semi-desert climatic conditions characterized by patches of scattered dry forests, Acacia woodlands, bush-land, savannah and scrubland (MOA, 2000).

\subsection{Experimental Protocols and Data Analysis}

Fresh and mature leaves and roots were collected from $P$. juliflora trees growing around Semera and Dubti area, North East Ethiopia. Topsoil, sub-soils and Litter fall samples were taken from $P$. juliflora shade and free area as control. Plant tissues have been washed several times by water and dried under natural light in open air. Leaf, litter fall and root samples were grounded and the powders were stored in plastic bottles at room temperature. The aqueous extracts of leaves, litter fall and roots were prepared by soaking in distilled water after mixing for 10 seconds and were kept at room temperature and dark conditions for 24 hours as Khan et al. (2011). Aqueous extracts were filtered with three layers of mash cloths and double layers of Whatman No.1 filter paper.

Test seeds were collected from Regional Research Center and agricultural offices. Seeds were surface sterilized in 15\% sodium hypochlorite for $20 \mathrm{~min}$ and rinsed several times with distilled water (Humaid and Warrag, 1998; Tinnin and Kirkpatrick, 1985). Based on seed size, 20 seeds of Z. mays, 50 seeds of P. maximum, 50 seeds of C. gayana, and 30 seeds of G. hirsutum (four replicates each) were evenly distributed on Whatman No.1 filter paper in sterile glass Petri dishes $(70 \mathrm{~mm})$ and watered with $4-7 \mathrm{ml}$ extract solution of different concentrations. The control group was treated with proportional amount of distilled water based on seed sizes.

Germination percentage and growth rate data analyzed by descriptive statistics and comparisons made by Analyses of Variance (ANOVA) using statistical package for social sciences (SPSS-20) software. Significance levels among treatment means compared using Tukey's Honestly Significant Difference Test at 5\% level of significance.

\section{RESULTS AND DISCUSSION}

\subsection{Effects of Different Extracts on Z. mays}

Results of analysis showed that all extract concentrations of leaves, roots and litter fall on shoot and root growth were significantly affected all the study species (Table 1). Radicle and plumule length of all the study species tended to decrease with increasing extract concentration except at 
medium $(10 \mathrm{~g} / \mathrm{l})$ root extract and litter fall extracts on maize. Related results indicated the allelopathic influence of aqueous extracts of Chrozophora obliqua on Z. mays (Khan et al., 2011). Several previous studies also showed that $P$. juliflora reduced grass fodder availability (Pasiecznik, 1999), density of native plants (Senait Regassa et al., 2007), decrease shoot and root elongation (Chang-Hung, 1999) and vegetation cover (Kahi, 2003).

Maize seeds treated with root extracts of $10 \mathrm{~g} / 1$ and litter fall extracts of $5 \mathrm{~g} / \mathrm{l}, 10 \mathrm{~g} / \mathrm{l}$ and $15 \mathrm{~g} / \mathrm{l}$ developed longer radicle than that of the control (Table 1). These results are also in accordance with the findings of aqueous extracts from E. globulus which increased Olea europaea subsp. Cuspidata germination rate and lengths of radicles and plumules (Amare Bitew, 2012).

Table 1. Mean of Radicle Elongation $(\mathrm{cm})$ of the Study Species Treated With Different Concentrations of $P$. Juliflora Aqueous Extracts.

\begin{tabular}{|c|c|c|c|c|c|}
\hline Extract & Extract & Panicum & Rodus & Maize & Cotton \\
\hline \multirow[t]{7}{*}{ Leaves } & Control & 2.88 & 2.17 & 4.27 & 1.80 \\
\hline & 5 & $1.44 * \mathrm{a}$ & $1.23^{* a}$ & 4.03 & $1.41^{* \mathrm{a}}$ \\
\hline & 10 & $1.27 * \mathrm{a}$ & $1.18^{* a}$ & $3.72^{* a}$ & $1.12^{* \mathrm{a}}$ \\
\hline & 15 & $0.53 * b$ & $0.78^{* b}$ & $2.54 * \mathrm{~b}$ & $1.02 * \mathrm{a}$ \\
\hline & 25 & $0.36^{* \mathrm{c}}$ & $0.33^{* \mathrm{c}}$ & $1.87^{* \mathrm{c}}$ & $0.17^{* \mathrm{c}}$ \\
\hline & 50 & $0.33^{* \mathrm{c}}$ & $0.20 * \mathrm{c}$ & $1.38^{* \mathrm{c}}$ & $0.10^{* \mathrm{c}}$ \\
\hline & 75 & $0.12^{* \mathrm{~d}}$ & $0.10^{* \mathrm{c}}$ & $1.33^{* c}$ & $0.00^{* \mathrm{c}}$ \\
\hline \multirow[t]{5}{*}{ Litter } & 5 & $1.82 * \mathrm{a}$ & $1.34^{* a}$ & 4.66 & $0.85^{* \mathrm{a}}$ \\
\hline & 10 & $1.63^{* a}$ & $1.10^{* b}$ & 4.79 & $0.65^{* \mathrm{a}}$ \\
\hline & 15 & $1.56^{* \mathrm{~b}}$ & $1.05^{* \mathrm{bc}}$ & 5.54 & $0.48 * \mathrm{~b}$ \\
\hline & 25 & $1.19 * b$ & $0.81 * \mathrm{c}$ & $2.14^{* a}$ & $0.20^{* \mathrm{c}}$ \\
\hline & 50 & $0.58 * \mathrm{c}$ & $0.43 * \mathrm{c}$ & $2.03^{* a}$ & $0.15^{* \mathrm{c}}$ \\
\hline \multirow[t]{7}{*}{ Root } & 5 & $0.33^{* c}$ & $0.27 * \mathrm{c}$ & $1.94^{* c}$ & $0.10^{* \mathrm{c}}$ \\
\hline & 5 & $1.96^{* a}$ & $1.94 * \mathrm{a}$ & 3.92 & $1.58^{* \mathrm{a}}$ \\
\hline & 10 & $1.81 * \mathrm{a}$ & $1.25 * \mathrm{~b}$ & $5.13^{* a}$ & $1.40^{* \mathrm{a}}$ \\
\hline & 15 & $1.59^{* b}$ & $1.08^{* b}$ & 4.08 & $0.74^{* b}$ \\
\hline & 25 & $1.49 * b$ & $0.72 * b \mathrm{c}$ & $3.33^{* b}$ & $0.30^{* \mathrm{c}}$ \\
\hline & 50 & $0.33^{* \mathrm{c}}$ & $0.40^{* \mathrm{c}}$ & $3.15^{* b}$ & $0.12^{* \mathrm{c}}$ \\
\hline & 75 & $0.36^{* c}$ & $0.16^{* c}$ & $2.05^{* c}$ & $0.10^{* \mathrm{c}}$ \\
\hline
\end{tabular}

Note: Level of significance is $\mathrm{P}<0.05$, Column with same letters in each treatment are the same groups.

The effects of leaf extracts on $G$. herisutum were found different. There was no elongation of radicle when treated with $75 \mathrm{gm} / 1$ of leaf extract and no plumule growth in $50 \mathrm{gm} / 1$ and $75 \mathrm{~g} / 1$ of 
other extracts (Tables $1 \& 2$ ). This is in line with aqueous extracts of $P$. juliflora leaves on Cynodon dactylon (Waller, 2003; Humaid and Warrag, 1998). Some researchers also reported that aqueous extract of $P$. juliflora inhibit wheat seeds germination and seedling growth with proportional inhibitory effect extracts concentration (Siddiqui et al., 2009).

Table 2. Mean of Plumule elongations $(\mathrm{cm})$ of study species in response to different concentrations of aqueous extracts of $P$. juliflora leaf, root and litter fall.

\begin{tabular}{|c|c|c|c|c|c|}
\hline Extracts & Conc. $(g / l)$ & Panicum & Rodus & Maize & Cotton \\
\hline & 0.00 & 3.50 & 3.18 & 5.21 & 1.91 \\
\hline \multirow[t]{6}{*}{ Leaves } & 5 & $2.19 * \mathrm{~b}$ & $2.10 * \mathrm{~b}$ & $3.80 * \mathrm{a}$ & 1.53 \\
\hline & 10 & $2.10 * \mathrm{~b}$ & $1.80 * \mathrm{bc}$ & $3.36 * a b$ & $1.34 * \mathrm{a}$ \\
\hline & 15 & $1.97^{* a}$ & $1.65 * \mathrm{c}$ & $2.05 * \mathrm{c}$ & $1.25^{* \mathrm{a}}$ \\
\hline & 25 & $1.88 * \mathrm{~b}$ & $1.57 * \mathrm{c}$ & $1.83 * \mathrm{c}$ & $0.20 * \mathrm{c}$ \\
\hline & 50 & $0.87 * \mathrm{~b}$ & $0.96^{* \mathrm{c}}$ & $1.71 * \mathrm{~cd}$ & $0.00 * \mathrm{c}$ \\
\hline & 75 & $0.22 * \mathrm{c}$ & $0.10 * \mathrm{~d}$ & $1.53 * \mathrm{~d}$ & $0.00 * \mathrm{c}$ \\
\hline \multirow[t]{7}{*}{ Litter } & 5 & 2.86 & $2.48^{* a}$ & $4.50 * \mathrm{a}$ & $0.99 * \mathrm{~b}$ \\
\hline & 10 & $2.50 * \mathrm{a}$ & $1.73^{* \mathrm{c}}$ & $3.61 * \mathrm{ab}$ & $0.86 * \mathrm{~b}$ \\
\hline & 15 & $2.34 * \mathrm{a}$ & $1.63^{* \mathrm{c}}$ & $3.52 * \mathrm{~b}$ & $0.53 * \mathrm{bc}$ \\
\hline & 25 & $2.22 * b$ & $1.55^{* \mathrm{c}}$ & $2.49 * \mathrm{c}$ & $0.20 * \mathrm{c}$ \\
\hline & 50 & $1.54 * \mathrm{~b}$ & $1.52 * \mathrm{c}$ & $1.30^{* \mathrm{~d}}$ & $0.00 * \mathrm{c}$ \\
\hline & 75 & $0.99 * b$ & $1.45^{* \mathrm{c}}$ & $1.67 * \mathrm{c}$ & $0.00 * \mathrm{c}$ \\
\hline & 5 & $2.38^{* \mathrm{~b}}$ & $2.33^{* b}$ & $4.48^{* \mathrm{a}}$ & 1.67 \\
\hline \multirow[t]{5}{*}{ Root } & 10 & $2.11 * b$ & $2.04 * \mathrm{~b}$ & $4.35^{* a}$ & $1.43^{* \mathrm{a}}$ \\
\hline & 15 & $1.89 * \mathrm{bc}$ & $1.98 * \mathrm{~b}$ & $3.83 * \mathrm{ab}$ & $1.07 * \mathrm{~b}$ \\
\hline & 25 & $1.77 * b c$ & $1.81 * \mathrm{bc}$ & $3.56^{* b}$ & $0.60 * \mathrm{c}$ \\
\hline & 50 & $0.98 * \mathrm{c}$ & $1.49 * \mathrm{c}$ & $3.43 * \mathrm{~b}$ & $0.00 * \mathrm{c}$ \\
\hline & 75 & $0.52 * \mathrm{c}$ & $1.38^{* \mathrm{c}}$ & $2.28 * \mathrm{c}$ & $0.00 * \mathrm{c}$ \\
\hline
\end{tabular}

Note: Level of significance is $\mathrm{P}<0.05$, Column with same letters in each treatment are the same groups.

\subsection{Effects of Under Canopy the Test Species}

Top and subsoil (0-10 and 10-20 $\mathrm{cm}$ depth) collected from $P$. juliflora under canopy showed differences in allelophathic effects (Fig 2). The topsoil showed significant inhibitory effects $(P$ $<0.05$ ) on radicle growth of all the test species except cotton. This could be due to accumulation 
of responsible compounds in the upper part of the soil after being released from the plant (Pasiecznik, 1999).

On the contrary, the subsoil has shown some stimulating effect on seedling growth of test grasses. This could be due to that either decomposition or transformation of the inhibiting compounds and not reaching the subsoil. This finding did not agree with Zainal et al. (1988), who reported that $P$. juliflora litter receiving soils always result in low fertility. However, it supports the idea that $P$. juliflora improves soil fertility for its $\mathrm{N}$-fixation (Aggrawal, 1998).

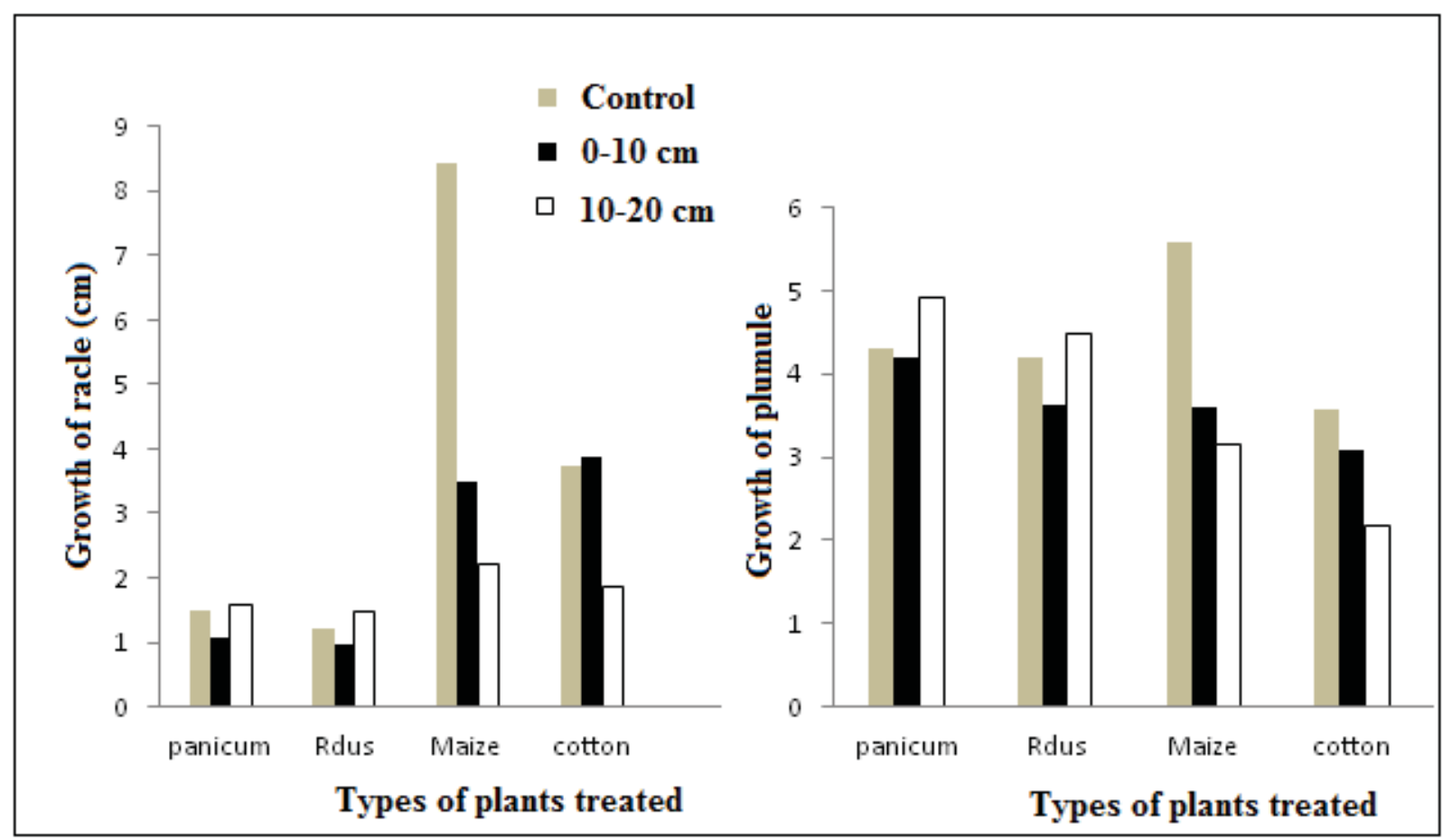

Figure 2. Effects $P$. juliflora under the canopy soils $(0-10 \& 10-20 \mathrm{~cm}$ depth $)$ on growth of the Radicle (left) and Plumule (right) of the study species

\subsection{Effects $P$. juliflora Extracts on Germination of Test Plants}

While C. gayana germination significantly inhibited by all types (of) extracts, but P. maximum was inhibited significantly only by leaf extracts. Leaves had the most allelophatic effect followed by litter fall and roots extracts (Fig 3). Earlier reports also indicated that fresh leaf extracts were found to have greater inhibitory impact on germination than extracts from stems, litter fall and fruit (Sen and Chawan, 1970). 
However, there were germination percentage reduction, Z. mays and G. herisutum seeds in all types of extracts, but not significantly different compared to control. This means that some species seeds germination processes may not be affected by external compounds. This also found to support investigation results of $P$. juliflora allelopathic effect on wheat and Chromolaena odorata extracts on cowpea (Okwulehie and Amazu, 2004).

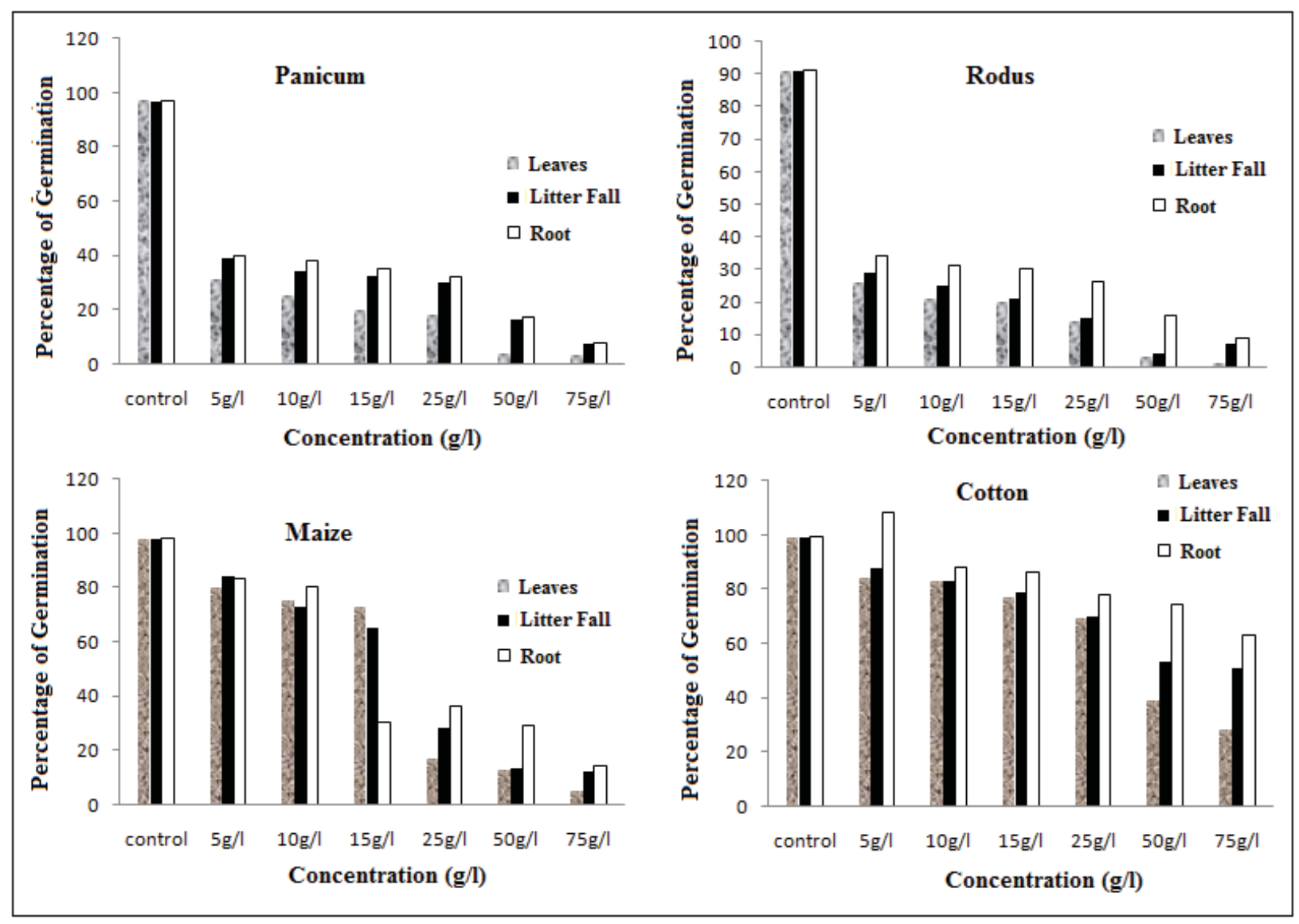

Figure 3. Germination percentage of the study species treated with of aqueous extracts of leaves, roots and litter of $P$. juliflora

\subsection{Effects of $\boldsymbol{P}$. juliflora Under-Canopy Soil on Germination}

The present study showed that P. juliflora under canopy soil has allelophatic effects on germination of useful plants in the study area. The topsoil found to have more deleterious effects than subsoil on percent of seed germination (Fig 4). This is may be because of high accumulation of allelochemicals released from P. juliflora litter fall or from root exudates on the surface. In addition, some chemicals found in P. juliflora like alkaloids and flavonoids are known to be 
rapidly degraded following senescence. While other chemicals may accumulate under tree canopy for longer time (Sola et al., 1992), its transformation is characteristics of soil microbes that may also affect the quantitative and qualitative availability of photochemical or the expression of allelopathic property (Pasiecznik, 1999).

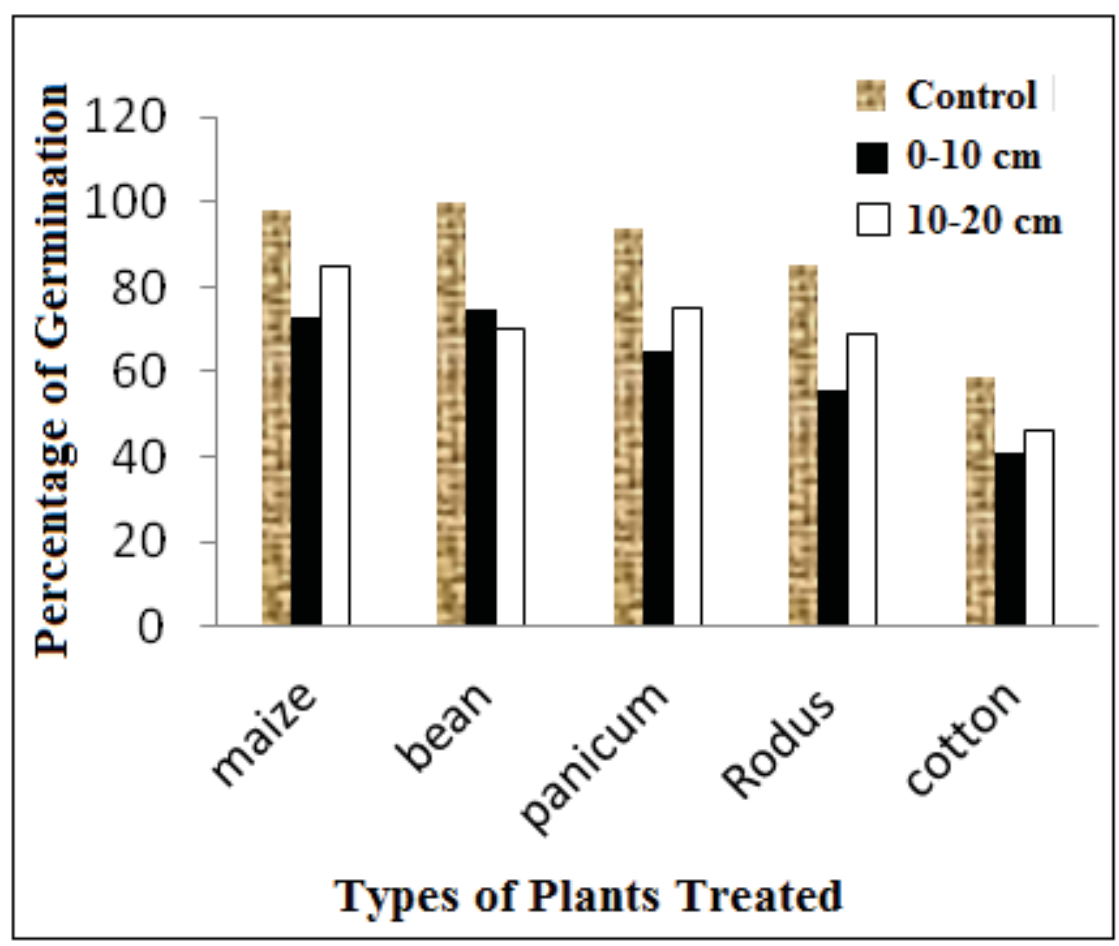

Figure 4. Effects of $P$. juliflora under canopy soils (depth of 0-10 \& 10-20 cm) on germination percentage of study species

\section{CONCLUSION}

The present study indicates that presence of water soluble and biodegradable phytotoxic substances of $P$. juliflora are capable of inhibiting germination and growth of tropical crops. The substance found in leaves, litter and root extracts as well as the under canopy topsoil have enough concentration of phototoxic compounds to affect nearby plants. Hence, it is capable of reducing germination, and significantly inhibiting seedlings growth of crops. For the open canopy of $P$. juliflora light prevention cannot explain why grasses eliminated after the introduction of the species. Allopathic exudates could be the reason why eastern Ethiopian grasslands invaded by the species. Thus, prevention of $P$. juliflora encroachment in to cultivation areas and reclamation of cleared area before cultivation is highly recommended. 


\section{ACKNOWLEDGMENTS}

We would like to acknowledge Dr. Ahmed, Ato Yimer, Dr. Wosenachew and Abadi, staff and authorities of Semera Animal Health Institute for the permission to use their laboratory settings. Thanks go Ato Ahmed, Yesefazer and Zinet, lab staffs who supported during the experiments and students of the Dubti Secondary School who helped during samples collection. We are grateful to Ato Shimeles, Kefeni and Wossen for their material, moral and financial supports.

\section{REFERENCE}

Aggarwal, R.K. 1993. Effect of Prosopis species on properties of arid zone soils. In: J.C. Tewari, N.M. Pasiecznik, L.N. Harsh and P.J.C. Harris (Eds.). Proceedings of conference on "Prosopis species in the Arid and Semi-Arid Zones of India" held in November 21-23, Jodhpur, India by The Prosopis Society of India and the Henry Doubleday Research Association, DFID, ISBN: 0905343212.

Amare, B. 2012. Allelopathic Effects of Eucalyptus globulus L. on Seed Germination and Early Growth of Some Monocot Crops around Kossober Town. M.Sc. Thesis, Bahir Dar University (unpubl.).

Chang-Hung, C. 1999. Roles of Allelopathy in Plant. Biodiversity and Sustainable Agriculture, Critical Reviews in Plant Sciences, 18(5):609-636.

El-keblawy, A \& Al-Rawai, A. 2006. Effect of salinity, temperature and light on germination of invasive P. juliflora (Sw.) DC. Journal of Arid Environment, 61:555-565.

Hedberg, I \& Edwards, S. (eds.) 1989. Pittosporaceae to Araliaceae, Vol. 3. Flora of Ethiopia. The National Herbarium, Addis Ababa, Ethiopia, 660p.

Hierro, J.L \& Callaway R.M. 2003. Allelopathy and exotic plant invasion. Plant and Soil, 256: 29-39.

Humaid, A.I \& Warrag, O.A.L. 1998. Allelopathic effects of mesquite (Prosopis juliflora) foliage on seed germination and seedling growth of Bermuda grass (Cynodon dactylon). Journal of Arid Environments, 38: 237-243.

Kahi, H. 2003. The effects of Prosopis juliflora and Accacia tortilis trees on understory plant species and soil properties on Njempas Flat, Thesis, Baringo District, Kenya (unpubl.). 
Khan, M., Mohammad, I., Musharaf, S., Hussain, F., Ali, S.G., Hameed, I \& Imdadullahd. 2011. Effect of aqueous extracts of Chrozophora obliqua (Del) Juss on germination and seedling growth of Zea mays. International Journal of Biosciences, 4: 94-99.

Minstry of Agriculture (MOA) 2000. Agro-Ecological Zones of Ethiopia. MoA, Addis Ababa, Ethiopia.

Okwulehie, I.C \& Amazu, O.M. 2004. Possible allelophatic effects of Siam weed (Chromolaena odorata) ((L) R.M. King and Robertson) extracts on germination and seedling growth of cowpea (Vigna Unguilata L.) and maize (Zea maiys L). Nigeria Agricultural of Journal, 35: 59-67.

Pasiecznik, N.M. 1999. Prosopis-pest or providence, weed or wonder tree? (Newsletter No. 28): European Tropical Forest research Network.

Sen, D.N \& Chawan, D.D. 1970. Ecology of desert plants and observations on their seedlings. Vegetatio, 21:375-397.

Senait Regassa, Agajie, T., Taye Tessema, Adefires W., Rezene F \& Getu E. (eds) 2007. Socioeconomic impacts and control baseline condition of Prosopis juliflora. Proceedings of the second workshop held on 29-30th November, Addis Ababa, EIAR, pp. 73-76.

Siddiqui, S., Bhardwaji, S., Khan, S.A \& Meghvanshi, M.K. 2009. Allelopathic effect of different concentration of water extracts of $P$. juliflora leaf on seed germination and radicle length of Wheat (Triticum aestivum Var. Lok-1). American Eurasian Journal of Scientific Research, 4(2):8-84.

Sola, N.H., Juliani, H.R \& Cabrera, J.L. 1992. Determination of some soil components under Prosopis ruscifolia. Agrochimica, 36: 148-153.

Tinnin, R.O \& Kirkpatrick, L.A. 1985. The Allelopathic influence of broad leaf trees and shrubs on seedling of Douglas fir. Forest Science, 31: 945-952.

Waller, G.R. 2003. Introduction-reality and future of allelopathy. In: F.A. Macias, J.C.G. Galindo, J.M.G. Molinillo and H.G. Culter (Eds). Allelopathy, Chemistry and Mode of Action of Allelochemicals, CRC Press, New York, pp. 1-12.

Zainal, A.S., Abdel-Rahim, A.M., Abu-Ali, R.M \& Radwan, S.S. 1988. Antimicrobial Substance(s) in the leaf litter of the xerophyte Prosopis juliflora. Zentralblatt Für Mikrobiologie (Elsevier - Gmbh), 143: 375-381. 